\title{
Trace element delivery for biogas production enhanced by alternative energy crops: results from two-year field trials
}

\author{
Wiebke Fahlbusch ${ }^{1 *} \mathbb{D}$, Katharina Hey ${ }^{2}$, Benedikt Sauer ${ }^{1}$ and Hans Ruppert ${ }^{1}$
}

\begin{abstract}
Background: Energy crop production for biogas still relies mainly on maize, but the co-digestion of alternative energy crops (legumes, amaranth, ryegrass, flower mixtures) with maize can have several advantages. First, a greater biodiversity in the fields; second, an enrichment of essential trace elements in biogas substrates (cobalt, nickel, manganese, and molybdenum); and third, less use of artificial trace element additives.

Methods: In two randomized field trials, 12 different variants of field crops in sole, double and intercropping were tested over a 2-year period. Dry matter yield, trace element content of the crops, and soil parameters like soil texture, $\mathrm{pH}$, and soil element concentration were determined. The trace element concentrations in biogas plants resulting from input mixtures of energy crops (legumes, amaranth, faba bean, and ryegrass) and maize are calculated.

Results: High dry matter yields were obtained for ryegrass, maize, winter faba bean maize, intercropping winter faba bean/triticale-maize, and intercropping rye/vetch-maize. The double croppings with maize reached highest total yields (ca. $30 \mathrm{t} \mathrm{DM} \mathrm{ha}^{-1}$ ). Total element deliveries from the harvest reveal large differences between the variants and the trace elements. Cobalt is provided most by summer faba bean maize and intercropping of winter faba bean/triticale-maize. Ryegrass can deliver the greatest amounts of Manganese and Molybdenum to biogas plants.

When these energy crops are added to conventional maize input for biogas production, the trace element concentration in the fermenter can be raised significantly, e.g., $0.03 \mathrm{~g} \mathrm{Co} \mathrm{t}^{-1} \mathrm{FM}$ can be attained compared to 0 . $003 \mathrm{~g} \mathrm{t}^{-1}$ with maize silage input only. Sufficient Co can be provided by addition of manure to the input mixture.

Conclusions: Alternative energy crops in combination with maize ensure a good dry matter yield per year and provide significantly more trace elements. However, these substrate mixtures alone do not provide enough trace elements, particularly Co. However, enough Co can be supplied by a small addition of manure.
\end{abstract}

Keywords: Cobalt, Nickel, Manganese, Molybdenum, Biogas, Energy crops, Faba bean, Intercropping, Trace elements

\footnotetext{
* Correspondence: wfahlbu@uni-goettingen.de

${ }^{1}$ Department of Sedimentology and Environmental Geology, Georg-August

University, Goldschmidtstraße 3, 37075 Göttingen, Germany

Full list of author information is available at the end of the article
}

(c) The Author(s). 2018 Open Access This article is distributed under the terms of the Creative Commons Attribution 4.0 International License (http://creativecommons.org/licenses/by/4.0/), which permits unrestricted use, distribution, and reproduction in any medium, provided you give appropriate credit to the original author(s) and the source, provide a link to the Creative Commons license, and indicate if changes were made. 


\section{Background}

Renewable electricity production from biogas is a promising renewable energy form which can mitigate climate change and decrease the dependence on fossil fuels. In Germany, there are 9300 biogas plants with a total installed electric output of $4.5 \mathrm{GW}$ [1].

Energy crop production for farmers offers many advantages, e.g., more stable delivery contracts for biogas substrates leading to stabilization of the revenues, the production of organic fertilizer in the form of biogas residue and a larger biodiversity on the fields [2].

In Germany, maize is the most commonly used energy crop with $72 \%$, followed by grass $(12 \%)$ and $7 \%$ of cereal whole crop silage [3]. Maize is used because of its very high dry matter and methane yield, and can be easily stored as silage for biogas fermenters. There are some negative traits about long-term maize cultivation, because it leads to soil degradation and decrease in soil organic matter. A 27-year field experiment showed that soil organic carbon decreased by $30 \%$ for continuous maize growth compared to only $3 \%$ for a permanent grass cover [4]. Palmer and Smith [5] stated high to severe levels of soil structural degradation on sites where late harvested crops such as maize had been grown. When maize is grown in monoculture, it may also promote pests like the European corn borer (Ostrinia nubilalis) [6].

Trace element needs of biogas fermenters and thresholds Low trace element (TE) contents in biogas fermenters cause instabilities and low biogas production rates. Cobalt (Co) in particular is a limiting factor for growth and activity of methanogenic microorganisms [7-11]. Alongside $\mathrm{Co}$, nickel (Ni), molybdenum (Mo), manganese (Mn), selenium (Se), and tungsten (W) are essential trace elements for biogas microorganisms [12]. Some authors give minimum thresholds for trace elements in biogas fermenters which should be surpassed to guarantee a stable biogas production. For Co, for example, Sauer [13] evaluated $0.07 \mathrm{mg} \mathrm{kg}^{-1} \mathrm{FM}$ and Pobeheim [9] $0.05 \mathrm{mg} \mathrm{kg}^{-1} \mathrm{FM}$. These thresholds depend on different fermenter parameters like the organic loading rate (OLR), the hydraulic retention time (HRT), and the biocenosis.

To avoid negative effects due to too low trace element supply there are two ways to conquer deficiencies. The elements can be supplied by addition of manure which has a high TE content or by addition of trace element additives. The application of high amounts of liquid manure however has the disadvantage that it mainly consists of water (about 6-8\% DM) occupying space in the biogas fermenter without contributing to the biogas yield [14].

Trace element additives are commonly used in more than 3.000 biogas plants in Germany. This number is a sound estimation by biogas scientists and is also given by executive staff of a biogas additive selling company. It is safe to assume that about every second biogas plant in Germany uses these kinds of trace element additives. In 2015, there were about 250 different biogas additives on the market [15]. This handling often stabilizes biogas production [11, 15] but bears environmental and health risks for operators and is expensive. The natural element cycle is disturbed with potential toxic (heavy) metals (Co, Ni, $\mathrm{Mn}, \mathrm{Mo}$ ) as these elements become enriched in the biogas residue used as an organic fertilizer [16]. Furthermore, the majority of Co production is located in the Democratic Republic of Congo, where labor conditions are questionable. A recently published report state human rights abuses by child labor and health problems of the workers [17]. For all these reasons, the application of element additives should be minimized. This study uses the approach of providing these trace elements with alternative energy crops to avoid or at least minimize the use of trace element additives.

\section{Physiological function of trace elements and uptake}

Different plant species have differing element uptake mechanisms and tissue structures resulting in different trace element concentrations in the plant matter. The trace elements $\mathrm{Ni}, \mathrm{Mn}$, and Mo are considered essential to higher plants but are needed only in small amounts [18]. Cobalt is reported as beneficial to plants [19-21] especially for Leguminosae, since Reisenauer [22] demonstrated the essential role of Co in biological nitrogen fixation (BNF).

$\mathrm{Mn}$ in plants is part of a large number of enzymes and is involved in redox processes in oxidation states II, III, and IV. It plays an important role in photosynthesis, first demonstrated for green algae chlorella [23]. Mo is an essential element for plants as well and is part of several enzymes [21, 24, 25]. The greatest concentrations of Mo were found in Leguminosae where it is mainly located between the leaf veins [26].

$\mathrm{Ni}$ belongs to the enzyme urease needed for the hydrolysis of urea [27]. Ni-deficiency leads to leaflet tip necrosis caused by urea [28]. All these trace elements can also be toxic to plants, but such high soil concentrations necessary will not be reached except in areas of non-ferrous mineral deposits or contaminated areas. In fact, it is more likely that deficiencies occur as partially stated for the European agricultural soil [29]. Co, $\mathrm{Ni}$, and $\mathrm{Mn}$ do have in common a higher uptake by plants at lower soil $\mathrm{pH}$. On the other hand, Mo is less mobile in acidic soil conditions [18].

\section{Aims of the study}

This study shows results of an interdisciplinary project which combines agronomic, (geo-)chemical and microbiological methods for an optimized and more sustainable biogas production with energy crops. Several alternative energy crops (e.g., legumes, amaranth or flowering plants) were tested in comparison to traditional energy crops (e.g., maize, ryegrass) in different cropping systems. This 
study comprises the first part of the project results: the soil properties, the element composition, dry matter yield of the energy crops and the combined results as flux of element $\left(\mathrm{g} \mathrm{ha}^{-1} \mathrm{a}^{-1}\right)$. The trace element concentrations provided here are valuable because there is very limited data on $\mathrm{Co}, \mathrm{Mn}$, Mo and $\mathrm{Ni}$ concentrations in whole plants available, especially for Co. These results together are the basis for hypothetical calculations of resulting element concentrations in biogas plants that arise from different input mixtures. This data is also required in the second stage of the project where the energy crop mixtures are tested in lab-scale biogas plants. The aim of the study is to give arguments for a broader energy crop as input into biogas plants.

This paper will provide the following:

- Trace element concentrations (Co, Mn, Mo, and Ni) of whole plants for a large variety of energy crops

- A new argument for a larger biodiversity in energy crop production

- Raise transparency and awareness of the use (and misuse) of trace element additives for biogas production.

\section{Methods}

\section{Soil properties}

2-year field trials were conducted at two contrasting sites in southern Lower Saxony, Germany. At the research farm Reinshof in the Leine valley (N $5{ }^{\circ} 29^{\prime} 23.41^{\prime \prime}$ E 9 96 $11.95^{\prime \prime}$; altitude $164 \mathrm{~m}$ ) and at Sömmerling in the Solling region (N 51 38'26.37' '; E 9 $40^{\circ} 15.46^{\prime \prime}$; altitude $251 \mathrm{~m}$ ). The soil at the fertile site Reinshof is classified as a haplic luvisol and at the marginal site Sömmerling as a cleyic cambisol. Available field capacity in the rooting depth at Reinshof and Sömmerling is $257 \mathrm{~mm}$ and $124 \mathrm{~mm}$, respectively. Long-term annual mean temperature is $9.2{ }^{\circ} \mathrm{C}$ at Reinshof and $9.0{ }^{\circ} \mathrm{C}$ at Sömmerling and the long-term annual precipitation $651 \mathrm{~mm}$ and $836 \mathrm{~mm}$, respectively [30].

The $\mathrm{pH}$ of the soil $\left(0.01 \mathrm{~mol} \mathrm{l}^{-1} \mathrm{CaCl}_{2}\right.$ [31] $)$ is 6.8 at Reinshof and 6.4 at Sömmerling. The parent materials of the Reinshof soil are fluviatile sediments derived from late quaternary loess and that of the Sömmerling are triassic sand- and siltstones with an addition of some loess. Further, important topsoil parameters are shown in Table 1. The extractable amounts of phosphorous (P) and potassium $(\mathrm{K})$ were measured in calcium acetate lactate solution (CAL) and magnesium $(\mathrm{Mg})$ measured in $\mathrm{CaCl}_{2}$ [32]. The soil particle size was analyzed by hydrometer analysis [33]. The experimental design was a randomized Semi-Latin square with four replications. The area of each plot was $9 \mathrm{~m} \times 7.5 \mathrm{~m}\left(67.5 \mathrm{~m}^{2}\right)$ at Reinshof and $4.5 \mathrm{~m} \times 7.5 \mathrm{~m}\left(33.75 \mathrm{~m}^{2}\right)$ at Sömmerling.
Table 1 Characteristics of topsoil $(0-30 \mathrm{~cm}) \pm$ SE (standard error of the mean)

\begin{tabular}{llll}
\hline Parameter & & Reinshof & Sömmerling \\
\hline $\mathrm{P}$ & $\mathrm{mg} 10 \mathrm{~g} \mathrm{~g}^{-1}, \mathrm{CAL}$ & $15.3 \pm 1.1$ & $11.8 \pm 2.3$ \\
$\mathrm{~K}$ & & $9.5 \pm 0.7$ & $20.8 \pm 1.2$ \\
$\mathrm{Mg}$ & $\mathrm{mg} 100 \mathrm{~g}^{-1}, \mathrm{CaCl}_{2}$ & $11.8 \pm 0.3$ & $7.1 \pm 0.2$ \\
Humus & $\%$ & $1.9 \pm 0.1$ & $1.9 \pm 0.05$ \\
Sand & $\%$ & $12.7 \pm 0.5$ & $33.5 \pm 0.4$ \\
Silt & & $69.4 \pm 0.3$ & $49.8 \pm 0.1$ \\
Clay & & $17.9 \pm 0.2$ & $16.7 \pm 0.4$ \\
$\mathrm{Al}$ & $\%$, total & $4.7 \pm 0.07$ & $4.1 \pm 0.09$ \\
$\mathrm{Fe}$ & & $1.8 \pm 0.03$ & $1.4 \pm 0.04$ \\
$\mathrm{Ti}$ & $0.4 \pm 0.002$ & $0.3 \pm 0.004$ \\
$\mathrm{Mn}$ & & $704 \pm 8$ & $479 \pm 23$ \\
$\mathrm{Cd}$ & & $0.45 \pm 0.02$ & $0.37 \pm 0.02$ \\
$\mathrm{Co}$ & & $7.1 \pm 0.1$ & $8.1 \pm 0.2$ \\
$\mathrm{Cu}$ & & $14.0 \pm 0.2$ & $7.0 \pm 0.2$ \\
$\mathrm{Mo}$ & & $0.7 \pm 0.1$ & $0.96 \pm 0.09$ \\
$\mathrm{Ni}$ & & $16.5 \pm 0.6$ & $11.8 \pm 0.6$ \\
$\mathrm{Zn}$ & & $54 \pm 1$ & $50 \pm 1$ \\
\hline
\end{tabular}

Crop species, cropping systems, and management

The plants were grown in 2014/2015 and 2015/2016, hereafter referred to as 2015 and 2016. Various farming systems were performed. The double cropping system is defined as a crop rotation with a first crop in winter and a succeeding second crop in summer. As winter crops winter faba bean, winter triticale, an intercropping of winter faba bean and winter triticale and an intercropping of rye and hairy vetch were grown. Maize was used as summer crop in this double croppings system. In contrast to this, the summer main crops summer faba bean, annual flower mixture (12 species), amaranth, maize, and the intercropping of amaranth and maize were grown after bare fallow over winter. Ryegrass, perennial flower mixture (25 species), and cup plant were grown as permanent crops for duration of the trial.

Cup plant could only be harvested once in 2016, as in planting year 2015 it formed only leaf rosettes. In the 2 years of field trials, different maize cultivars as second crops were used, because the cultivar used in 2015 did not reach full maturity. Standard crop management practices for fertilization and plant protection were applied. Nitrogen $(\mathrm{N})$ fertilizer was applied relating to the default nominal value of $\mathrm{N}$ [34]. For unknown crops, the amount of $\mathrm{N}$ fertilizer was determined by recommendations of breeders and other study results. In any case, the amount of mineral $\mathrm{N}$ in the soil (Nmin) was taken into account and subtracted from the nominal value. The fertilizer was applied as a combination of organic and mineral fertilizer. See Table 2 for additional cultivation parameters. 
Table 2 Cultivars of the tested variants and cultivation dates at the main field trials Reinshof and Sömmerling in both years of trial (2015 and 2016)

\begin{tabular}{|c|c|c|c|c|c|c|}
\hline Variant & Cultivar & Seed & $\begin{array}{l}\text { Sowing } \\
\text { Reinshof }\end{array}$ & $\begin{array}{l}\text { Harvest } \\
\text { Reinshof }\end{array}$ & $\begin{array}{l}\text { Sowing } \\
\text { Sömmerling }\end{array}$ & $\begin{array}{l}\text { Harvest } \\
\text { Sömmerling }\end{array}$ \\
\hline $\begin{array}{l}\text { Per. flower mix. } \\
\text { (PF Mix) }\end{array}$ & BG 70 & $10 \mathrm{~kg} \mathrm{ha}^{-1}$ & 08-May-2015 & $\begin{array}{l}\text { 01-Sep-2015 } \\
\text { 15-Aug-2016 }\end{array}$ & 12-May-2015 & $\begin{array}{l}\text { 24-Aug-2015 } \\
\text { 18-Aug-2016 }\end{array}$ \\
\hline Ryegrass (RG) & Alligator & $40 \mathrm{~kg} \mathrm{ha}^{-1}$ & 01-Oct-2014 & $\begin{array}{l}3 \text { cuts } 2015 \\
3 \text { cuts } 2016\end{array}$ & 25-Mar-2015 & 3 cuts 2016 \\
\hline Cup plant (CP) & Chrestensen & $4 \mathrm{pl} \mathrm{m}^{-2}$ & 19-May-2015 & 31-Aug-2016 & 20-May-2015 & 25-Aug-2016 \\
\hline $\begin{array}{l}\text { Ann. flower mix. } \\
\text { (AF Mix) }\end{array}$ & BG 80 & $10 \mathrm{~kg} \mathrm{ha}^{-1}$ & $\begin{array}{l}\text { 08-May-2015 } \\
\text { 12-May-2016 }\end{array}$ & $\begin{array}{l}05-O c t-2015 \\
11-O c t-2016\end{array}$ & $\begin{array}{l}\text { 12-May-2015 } \\
\text { 17-May-2016 }\end{array}$ & $\begin{array}{l}06-O c t-2015 \\
04-O c t-2016\end{array}$ \\
\hline $\begin{array}{l}\text { Su faba bean } \\
\text { (FB Su) }\end{array}$ & Fanfare & $40 \mathrm{~s} \mathrm{~m}^{-2}$ & $\begin{array}{l}\text { 09-Apr-2015 } \\
\text { 16-Mar-2016 }\end{array}$ & $\begin{array}{l}15-J u l-2015 \\
12-J u l-2016\end{array}$ & $\begin{array}{l}\text { 25-Mar-2015 } \\
\text { 17-Mar-2016 }\end{array}$ & $\begin{array}{l}16-J u l-2015 \\
13-J u l-2016\end{array}$ \\
\hline Amaranth (A) & Bärnkrafft & $40 \mathrm{~s} \mathrm{~m}^{-2}$ & $\begin{array}{l}\text { 18-May-2015 } \\
\text { 10-May-2016 }\end{array}$ & $\begin{array}{l}05-O c t-2015 \\
11-O c t-2016\end{array}$ & $\begin{array}{l}\text { 12-May-2015 } \\
17-\text { May-2016 }\end{array}$ & $\begin{array}{l}06-O c t-2015 \\
04-O c t-2016\end{array}$ \\
\hline Maize-main (M) & Amadeo & $25 \mathrm{sm}^{-2}$ & $\begin{array}{l}\text { 11-May-2015 } \\
\text { 10-May-2016 }\end{array}$ & $\begin{array}{l}29-S e p-2015 \\
12-S e p-2016\end{array}$ & $\begin{array}{l}\text { 12-May-2015 } \\
\text { 11-May-2016 }\end{array}$ & $\begin{array}{l}\text { 30-Sep-2015 } \\
19-S e p-2016\end{array}$ \\
\hline $\begin{array}{l}\text { Amaranth/maize } \\
\text { (AM) }\end{array}$ & $\begin{array}{l}\text { Bärnkrafft/ } \\
\text { Amadeo }\end{array}$ & $\begin{array}{l}78 \mathrm{sm}^{-2} \\
10 \mathrm{sm}^{-2}\end{array}$ & $\begin{array}{l}\text { 11-May-2015 } \\
\text { 10-May-2016 }\end{array}$ & $\begin{array}{l}\text { 29-Sep-2015 } \\
12-S e p-2016\end{array}$ & $\begin{array}{l}\text { 12-May-2015 } \\
\text { 11-May-2016 }\end{array}$ & $\begin{array}{l}\text { 30-Sep-2015 } \\
19-S e p-2016\end{array}$ \\
\hline $\begin{array}{l}\text { Wi faba bean } \\
\text { (FB Wi) }\end{array}$ & Nordica & $25 \mathrm{sm}^{-2}$ & $\begin{array}{l}01-O c t-2014 \\
06-O c t-2015\end{array}$ & $\begin{array}{l}\text { 02-Jun-2015 } \\
\text { 06-Jun-2016 }\end{array}$ & $\begin{array}{l}06-O c t-2014 \\
13-O c t-2015\end{array}$ & $\begin{array}{l}\text { 09-Jun-2015 } \\
\text { 13-Jun-2016 }\end{array}$ \\
\hline Wi triticale (Tri) & Balu & $375 \mathrm{~s} \mathrm{~m}^{-2}$ & $\begin{array}{l}\text { 01-Oct-2014 } \\
03-O c t-2015\end{array}$ & $\begin{array}{l}\text { 02-Jun-2015 } \\
\text { 06-Jun-2016 }\end{array}$ & $\begin{array}{l}06-O c t-2014 \\
13-O c t-2015\end{array}$ & $\begin{array}{l}\text { 09-Jun-2015 } \\
\text { 13-Jun-2016 }\end{array}$ \\
\hline $\begin{array}{l}\text { Faba bean/trit } \\
\text { (FB Wi Tri) }\end{array}$ & $\begin{array}{l}\text { Nordica/ } \\
\text { Balu }\end{array}$ & $\begin{array}{l}25 \mathrm{~s} \mathrm{~m}^{-2} \\
281 \mathrm{~s} \mathrm{~m}^{-2}\end{array}$ & $\begin{array}{l}01-O c t-2014 \\
06-O c t-2015\end{array}$ & $\begin{array}{l}\text { 02-Jun-2015 } \\
\text { 06-Jun-2016 }\end{array}$ & $\begin{array}{l}\text { 06-Oct-2014 } \\
13-O c t-2015\end{array}$ & $\begin{array}{l}\text { 09-Jun-2015 } \\
\text { 13-Jun-2016 }\end{array}$ \\
\hline Rye/vetch (RV) & $\begin{array}{l}\text { Conduct/ } \\
\text { Welta }\end{array}$ & $120 \mathrm{~kg} \mathrm{ha}^{-1}$ & $\begin{array}{l}\text { 01-Oct-2014 } \\
03-O c t-2015\end{array}$ & $\begin{array}{l}\text { 02-Jun-2015 } \\
\text { 06-Jun-2016 }\end{array}$ & 13-Oct-2015 & 13-Jun-2016 \\
\hline $\begin{array}{l}\text { Maize } \\
\text { (second) (M) }\end{array}$ & $\begin{array}{l}\text { Simpatico } \\
\text { Cathy (Re)/ P7326 (Sö) }\end{array}$ & $9 \mathrm{sm}-2$ & $\begin{array}{l}\text { 08-Jun-2015 } \\
\text { 10-Jun-2016 }\end{array}$ & $\begin{array}{l}21-O c t-2015 \\
27-O c t-2016\end{array}$ & $\begin{array}{l}\text { 17-Jun-2015 } \\
\text { 21-Jun-2016 }\end{array}$ & $\begin{array}{l}\text { 05-Nov-2015 } \\
31-\text { Oct-2016 }\end{array}$ \\
\hline
\end{tabular}

$s$ seeds, $p /$ plants, Re Reinshof, Sö Sömmerling

The previous crop at Reinshof was winter wheat in both years. At Sömmerling, it was rapeseed in the first year and winter wheat in the second year. After the previous crop, the soil was plowed in the first and reduced cultivated in the second year. Seed-bed cultivation took place before sowing in autumn and spring, depending on variant.

The winter crops as well as ryegrass were sown after stubble cultivation and ploughing in the first year. In the second year, only a reduced tillage after the previous crop was performed. The perennial crops in the first year and the summer main crops in both years were grown after seed-bed cultivation in spring. The seeds of the partners of the intercropping variants were sown in alternating rows.

\section{Sampling and analysis of yield and dry matter}

The sampling and analysis of dry matter yield at Reinshof and Sömmerling were performed between June and October 2015 and between June and November 2016 (Table 2). All variants except ryegrass were harvested once a year. Due to problems in establishing ryegrass at Sömmerling in autumn 2014, the results are only shown for three cuts of ryegrass in 2016. At Reinshof, there were three cuts in both years. To determine dry matter yield a sample of $1 \mathrm{~m} \times 1 \mathrm{~m}$ was harvested for all variants except for maize. Plants were cut close to soil surface by hand. For maize, a sample of $1.5 \mathrm{~m} \times 1 \mathrm{~m}$ cut at approximately $7 \mathrm{~cm}$ above soil surface was harvested. The plant material was dried at $105^{\circ} \mathrm{C}$ for $48 \mathrm{~h}$. All variants were harvested at silage maturity, which is suitable for use in biogas production. Unfortunately, on site Reinshof in 2016, maize as second crop was lost in the variants triticale, intercropping of faba bean/triticale, and rye/vetch. Therefore, the yield of this second maize was estimated from the plots of second maize of the variant winter faba bean.

\section{Sampling for trace element analysis}

All plant samples for trace element analysis were collected as whole plants (aboveground plant parts without roots) on the harvest dates listed in Table 2. The soil samples were taken up to a depth of $30 \mathrm{~cm}$ in April 2015. The samples were air dried and sieved to $<2 \mathrm{~mm}$ in grain size. A minimum of $100 \mathrm{~g}$ of the soils and $500 \mathrm{~g}$ of the plant fresh matter were dried at $105{ }^{\circ} \mathrm{C}$. The soils 
were ground in an agate ball mill (Fritsch Pulverisette 5) to $<0.063 \mu \mathrm{m}$, and the plants were cut in a universal cutting mill (Fritsch Pulverisette 19) to $<0.5 \mathrm{~mm}$. Aliquots of $150 \mathrm{mg}$ of soil and $700 \mathrm{mg}$ of plant powder were completely digested with a mixture of ultra-pure concentrated $\mathrm{HNO}_{3}, \mathrm{HClO}_{4}$, and $\mathrm{HF}$ in closed ultra-clean PTFE vessels (PicoTrace, Bovenden, Acid sample digestion system, DAS 30). For the soil samples, a small amount of $\mathrm{HCl}$ was added to completely dissolve precipitated aluminum and iron oxide hydroxides. The soil solutions were diluted to $100 \mathrm{ml}$, the plant solutions to $50 \mathrm{ml}$ before measurement. In addition, blank solutions without sample material were added in the digestion process to ensure that the handling was clean without detectable contamination from the reagents, the digestion, and the measurement process. In the resulting clear sample solutions, 47 elements were quantified by Inductively Coupled Plasma Optical Emission Spectrometry (ICP-OES, Agilent 5100 VDV) and mass spectrometry (ICP-MS, Thermo Scientific iCAP Q). The limit of detection was calculated by the 3-fold standard deviation of the blank concentrations for each analysis batch. The precision and accuracy of the digestion process and the ICP devices were tested by analyzing several international reference samples and one in-house standard. The accuracy describes the deviation between measured and reference value. In general, for the main elements, the accuracy was between 5 and $10 \%$. For the trace elements, typical average accuracies were between 10 and $20 \%$.

\section{Correction for adhering particles}

A total digestion process of the plant samples was performed. To access physiological concentrations resulting only from plant uptake, the values were corrected for adhering dust and soil particles. For plants grown on open field, a small amount of adhering soil or dust particles cannot be avoided. Severe soil "contamination" was washed off before further sample preparation. The concentrations were corrected with the median transfer factor $(\mathrm{TF}=$ conc. in plant/conc. in soil) of several elements with a very small translocation into the plant. For a detailed description refer to Method 3 in Pospiech et al. [35]. All element plant concentrations in this work were corrected this way. This was most important for Co and $\mathrm{Ni}$. The concentrations of $\mathrm{Mn}$ and Mo remain mostly unchanged by the correction, owing to their larger TF.

\section{Statistical analysis}

Statistical tests were performed to test, whether the difference in yield or the differences in element delivery were significantly different. The statistical method used was a linear mixed-effects model to account for the design and the treatment effect (variant). Effects for year and site were assumed to be fixed. Blocks were treated as random. The statistical analysis was done with $R$,
Version: 3.4.2 [36] and the packages lme4 [37] and multcomp [38]. The graphical representations with the package ggplot2 [39]. The significance level was set at 5\%, and if significant results were found, Tukey's HSD test (honestly significant difference) was performed to obtain pairwise mean comparisons.

\section{Results and discussion \\ Dry matter yield}

Significant effects of variant, year, site, and significant interactions of variant $\times$ year and variant $\times$ site were detected for yield (Table 3). Therefore, pairwise mean comparisons of crop species were conducted separately for each year and each site (Fig. 1).

The crops at site Reinshof generally reached greater yields than the crops at Sömmerling. This was most likely the result of the better soil texture, soil quality, and available field capacity of the soil at the site Reinshof. The greatest yields at both sites and years were reached for the double cropping system of triticalemaize, intercropping faba bean/triticale-maize, and intercropping rye/vetch-maize. In 2015, about 25 t DM ha $^{-1}$ and in 2016 about $30 \mathrm{t} \mathrm{DM} \mathrm{ha}^{-1}$ were harvested for these variants at site Reinshof. First crops contributed considerably to the total dry matter yield with percentages between $49 \%$ (winter faba bean) and 57\% (rye/ vetch) in 2015 and 32\% (winter faba bean) and 57\% (triticale) in 2016. This is consistent with Graß et al. [40] who also states high dry matter yields in double cropping systems. Like in this study, they found highest yields in variants with cereal-based first crops.

Maize as sole crop and the intercropping of amaranth/ maize reached high dry matter yields with 22 to $24 \mathrm{t} \mathrm{DM} \mathrm{ha}^{-1}$ at Reinshof, and slightly smaller yields on site Sömmerling. Though the proportion of amaranth in this intercropping was very small (about $2 \%$ amaranth, 98\% maize, data not shown), because maize suppressed amaranth during growth in this kind of sowing method.

The differences in yield between the variants of the double cropping system and maize were mostly insignificant, apart from Reinshof in 2016. In 2015, only triticale-maize at Sömmerling had significantly greater yield than maize as main crop. In 2016, the double

Table 3 Results of the $p$ values of the fixed effects in linear model for yield and for element delivery (Co, Mn, Mo, Ni)

\begin{tabular}{llllll}
\hline & Yield & Co & $\mathrm{Mn}$ & $\mathrm{Mo}$ & $\mathrm{Ni}$ \\
\hline Variant & $<0.0001$ & $<0.0001$ & $<0.0001$ & $<0.0001$ & $<0.0001$ \\
Year & $<0.0001$ & 0.0470 & $<0.0001$ & 0.0011 & n.s. \\
Site & $<0.0001$ & 0.0028 & $<0.0001$ & $<0.0001$ & $<0.0001$ \\
Variant ×year & 0.0039 & n.s. & $<0.0001$ & n.s. & $<0.0001$ \\
Variant $\times$ site & $<0.0001$ & 0.0019 & n.s. & $<0.0001$ & 0.0051 \\
\hline
\end{tabular}

n.s. $=$ not significant, significance level is 0.05 


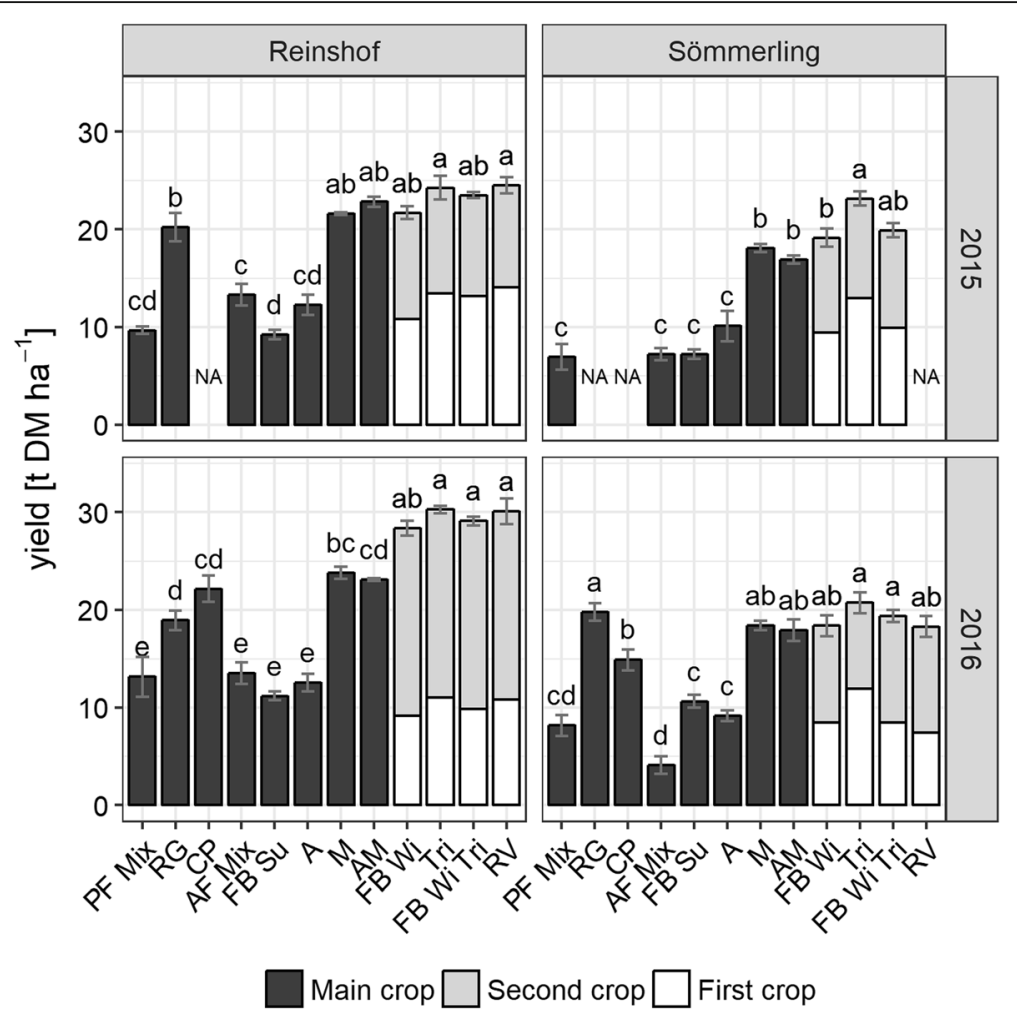

Fig. 1 Dry matter yield. Yield in t DM ha ${ }^{-1}$ of different energy crops and cropping systems. Maize as succeeding second crop (stacked bars). Different letters indicate significant differences between the variants from Tukey's HSD Test. Error bars = standard errors (SE) of cumulative yield. $N A=$ not available, $P F M i x=$ perenn. Flow. $m i x, R G=$ ryegrass, $C P=$ cup plant, $A F$ mix = annual flow. $M i x, A=$ amaranth, $M=m a i z e, A M=$ amar. $/$ maize, FB Wi = wi faba bean, Tri = triticale, FB Wi Tri = wi faba bean/triticale, RV= rye/vetch

cropping of triticale-maize, intercropping faba bean/triticale-maize, and the intercropping rye/vetch-maize at Reinshof, had significantly greater yields than maize as main crop. Ryegrass also reached good results in both years on both sites (20-22 t DM ha ${ }^{-1}$ ). Interestingly, at Sömmerling ryegrass showed greater yield figures even if it is not statistically significant greater than maize and a comparable yield to the highest yielding variants at this site. As in this case, in 2015 at site Reinshof, the yield of ryegrass was not significantly different with that of maize. The flowering mixtures (annual and perennial) could not compete with the high yielding crops and achieved only less than half of the maximum yields at each site and year. A slight yield increase from the first to the second year could be observed for the perennial flower mixture. In recent years, perennial wild plant mixtures for biogas use gained increasing attention in Germany because of their numerous ecological benefits such as permanent soil coverage, enhanced biodiversity, or a habitat function for various species. Dry matter yields between 3 and $23 \mathrm{t} \mathrm{DM} \mathrm{ha}^{-1}$ depending on the kind of wild plant mixture, year of use as a permanent crop, and site were reported in the literature [41]. With a maximum yield of $13 \mathrm{t} \mathrm{DM} \mathrm{ha}^{-1}$ at Reinshof in the second year, the yield potential of a wild plant mixture was most probably not reached, but may increase in later years of cultivation.

At Reinshof, cup plant achieved a high dry matter yield of about $22 \mathrm{t}$ DM ha ${ }^{-1}$ and did not differ significantly from the yield of main crop maize. This level of yield could not be achieved by cup plant in Sömmerling; on this site, the plants showed signs of water deficiency. A greater drought-related above-ground dry matter reduction for cup plant than for other crops was also observed by [42]. Yield figures comparable to maize could only be attained at sites with a good water supply. Under Bavarian cultivation conditions about 16 to $22 \mathrm{t} \mathrm{DM} \mathrm{ha}^{-1}$ were measured for several years [43].

\section{Trace element concentrations in the plants}

The trace element concentrations of the plant variants are shown in Table 4. The main result was that the crops mainly used as substrates for biogas production in the field trial: maize and triticale, showed the lowest concentrations of $\mathrm{Co}, \mathrm{Ni}$, and $\mathrm{Mn}$.

Different element concentrations of the plants between both field trial sites were detected, showing an influence of the different soil properties on element uptake. Also, 
Table 4 Element contents in $\mathrm{mg} \mathrm{kg}^{-1}$ in above-ground plant biomass, values represent means \pm sd (standard deviation) from samples of 2015 and 2016; table sorted by site and decreasing cobalt concentration

\begin{tabular}{|c|c|c|c|c|c|}
\hline Variant & $n$ & Co & $\mathrm{Mn}$ & Mo & $\mathrm{Ni}$ \\
\hline \multicolumn{6}{|l|}{ Reinshof } \\
\hline Faba bean (Su) & 8 & $0.188 \pm 0.037$ & $42.6 \pm 7.1$ & $0.64 \pm 0.19$ & $0.93 \pm 0.20$ \\
\hline Faba bean (Wi) & 8 & $0.127 \pm 0.029$ & $33.2 \pm 5.8$ & $0.86 \pm 0.26$ & $0.67 \pm 0.16$ \\
\hline PF mix & 8 & $0.059 \pm 0.009$ & $31.7 \pm 4.5$ & $0.52 \pm 0.15$ & $0.36 \pm 0.07$ \\
\hline Amaranth & 8 & $0.051 \pm 0.007$ & $44.5 \pm 10.2$ & $0.68 \pm 0.36$ & $0.17 \pm 0.05$ \\
\hline Faba bean/trit & 8 & $0.050 \pm 0.018$ & $30.6 \pm 2.5$ & $1.14 \pm 0.30$ & $0.35 \pm 0.09$ \\
\hline Cup plant & 4 & $0.028 \pm 0.006$ & $25.1 \pm 2.8$ & $0.08 \pm 0.02$ & $0.33 \pm 0.03$ \\
\hline AF mix & 8 & $0.027 \pm 0.012$ & $37.5 \pm 8.1$ & $0.39 \pm 0.21$ & $0.22 \pm 0.05$ \\
\hline Ryegrass & 24 & $0.020 \pm 0.012$ & $64.5 \pm 25.6$ & $2.50 \pm 1.30$ & $0.71 \pm 0.18$ \\
\hline Amaranth/maize & 8 & $0.011 \pm 0.002$ & $19.4 \pm 0.5$ & $0.43 \pm 0.15$ & $0.14 \pm 0.01$ \\
\hline Rye/vetch & 8 & $0.010 \pm 0.007$ & $18.6 \pm 3.3$ & $1.00 \pm 0.30$ & $0.13 \pm 0.07$ \\
\hline Triticale (Wi) & 8 & $0.010 \pm 0.004$ & $26.3 \pm 3.9$ & $1.33 \pm 0.18$ & $0.17 \pm 0.11$ \\
\hline Maize & 7 & $0.009 \pm 0.005$ & $18.2 \pm 1.6$ & $0.40 \pm 0.18$ & $0.14 \pm 0.04$ \\
\hline \multicolumn{6}{|l|}{ Sömmerling } \\
\hline Faba bean (Su) & 8 & $0.269 \pm 0.074$ & $44.3 \pm 11.6$ & $0.35 \pm 0.18$ & $0.53 \pm 0.14$ \\
\hline Faba bean (Wi) & 8 & $0.148 \pm 0.065$ & $40.1 \pm 12.3$ & $0.36 \pm 0.17$ & $0.35 \pm 0.10$ \\
\hline AF mix & 8 & $0.143 \pm 0.073$ & $43.6 \pm 9.6$ & $0.18 \pm 0.05$ & $0.27 \pm 0.08$ \\
\hline Amaranth & 8 & $0.130 \pm 0.052$ & $50.3 \pm 30.6$ & $0.38 \pm 0.12$ & $0.17 \pm 0.09$ \\
\hline PF mix & 8 & $0.126 \pm 0.067$ & $35.0 \pm 9.1$ & $0.33 \pm 0.10$ & $0.26 \pm 0.07$ \\
\hline Faba bean/trit & 8 & $0.111 \pm 0.041$ & $32.5 \pm 6.8$ & $0.31 \pm 0.13$ & $0.27 \pm 0.07$ \\
\hline Cup plant & 4 & $0.044 \pm 0.035$ & $32.9 \pm 6.1$ & $0.09 \pm 0.02$ & $0.28 \pm 0.05$ \\
\hline Ryegrass & 12 & $0.034 \pm 0.019$ & $77.6 \pm 21.0$ & $1.30 \pm 0.20$ & $0.42 \pm 0.13$ \\
\hline Rye/vetch & 4 & $0.031 \pm 0.012$ & $22.1 \pm 5.3$ & $0.58 \pm 0.23$ & $0.23 \pm 0.16$ \\
\hline Amaranth/maize & 8 & $0.014 \pm 0.007$ & $18.3 \pm 1.5$ & $0.32 \pm 0.12$ & $0.09 \pm 0.01$ \\
\hline Triticale (Wi) & 8 & $0.011 \pm 0.003$ & $20.4 \pm 4.8$ & $0.52 \pm 0.34$ & $0.09 \pm 0.06$ \\
\hline Maize & 8 & $0.008 \pm 0.007$ & $16.9 \pm 3.3$ & $0.32 \pm 0.17$ & $0.08 \pm 0.02$ \\
\hline
\end{tabular}

PF mix = perennial flower mixture, $A F$ mix = annual flower mixture

the statistic test on influence of the site for the delivery rates state a significant effect of the field site. However, the order of element concentrations between the variants was similar on each site, showing that the plant species itself did have a great influence on element accumulation from soil to plant. The greatest Co concentrations of $0.19 \mathrm{mg} \mathrm{kg}^{-1} \mathrm{DM}$ (Reinshof) and $0.27 \mathrm{mg} \mathrm{kg}^{-1} \mathrm{DM}$ (Sömmerling) were analyzed in the legumes summer faba bean, and in winter faba bean ( 0.13 to $\left.0.15 \mathrm{mg} \mathrm{kg}^{-1} \mathrm{DM}\right)$ (Table 4). The greatest $\mathrm{Ni}$ concentrations were also found in faba bean plants: $0.93 \mathrm{mg} \mathrm{kg}^{-1} \mathrm{Ni}$ (Reinshof) and $0.53 \mathrm{mg} \mathrm{kg}^{-1}$ (Sömmerling) for summer variety and $0.67 \mathrm{mg} \mathrm{kg}^{-1}$ (Reinshof) and $0.35 \mathrm{mg} \mathrm{kg}^{-1}$ (Sömmerling) for winter variety of faba bean. These findings correspond to literature which also reports that Mo is essential for Leguminosae [24, 25]. The greatest concentrations of Mn were analyzed in ryegrass $\left(64.5 \mathrm{mg} \mathrm{kg}^{-1}\right.$ (Reinshof) and $77.6 \mathrm{mg} \mathrm{kg}$ (Sömmerling). Second highest ranged amaranth samples with $47 \mathrm{mg} \mathrm{Mn} \mathrm{kg}{ }^{-1}$ and summer faba bean with $44 \mathrm{mg} \mathrm{Mn} \mathrm{kg}^{-1}$ (average of both sites).

Most plant variants belonging to the Poaceae family (maize, rye, triticale) reveal small $\mathrm{Co}$ and $\mathrm{Ni}$ trace elem-

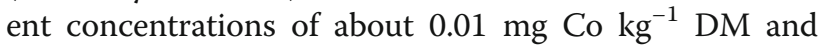
about $0.1 \mathrm{mg} \mathrm{Ni} \mathrm{kg}^{-1} \mathrm{DM}$ at both sites (Table 4). Co and $\mathrm{Ni}$ concentrations were particularly low in maize, triticale, and in the intercroppings rye/vetch and amaranth/ maize ranging between 0.008 and $0.01 \mathrm{mg} / \mathrm{kg}$ for Co and 0.08 and $0.17 \mathrm{mg} / \mathrm{kg} \mathrm{DM}$ for Ni. Ryegrass plants show the highest $\mathrm{Co}$ and $\mathrm{Ni}$ concentrations from all plants of the sweet grass family (Poaceae) with 0.02 (Reinshof) and $0.034 \mathrm{mg} \mathrm{Co} \mathrm{kg}^{-1}$ (Sömmerling) and 0.71 (Reinshof) and $0.42 \mathrm{mg} \mathrm{Ni} \mathrm{kg}^{-1}$ (Sömmerling).

The concentrations of $\mathrm{Co}, \mathrm{Ni}$, and $\mathrm{Mn}$ in intercropping rye/vetch only range slightly above triticale or maize (Table 4), although vetch plants alone did have elevated $\mathrm{Ni}$ and Co concentrations (data not shown). This 
was because vetch only reached less than $5 \%$ of total DM yield of the intercropping (data not shown). The same was true for amaranth/maize where amaranth had less than $5 \%$ of total DM yield. Only the intercropping faba bean/ triticale had almost equal yield contributions of both plants, resulting also in medium concentrations between both plants as sole crops (especially for $\mathrm{Co}$ ). The flowering mixtures (annual and perennial) also show elevated trace elements, for example, $0.059 \mathrm{mg} \mathrm{Co} \mathrm{kg}{ }^{-1}$ (Reinshof) and $0.36 \mathrm{mg} \mathrm{Ni} \mathrm{kg}^{-1}$ (Sömmerling). Although these consisted of several plant species they show a narrow standard deviation.

\section{Element delivery from harvest}

The amount of trace element (TE) per variant is called element delivery, as the focus is on the potential to deliver TE to biogas plants. However, the approach is the same for element amounts extracted from the soil. As well as for yield, significant effects of variant, year, site, and the interaction of variant $\times$ year and variant $\times$ site were detected for the element deliveries of $\mathrm{Co}, \mathrm{Mn}, \mathrm{Mo}$, and $\mathrm{Ni}$ (Table 3). The amount of TE harvest of $\mathrm{Co}, \mathrm{Ni}$, $\mathrm{Mo}$, and $\mathrm{Mn}$ was calculated for main crops ryegrass, cup plant, amaranth, maize, and summer faba bean, as well as for the variants of the double cropping systems: winter faba bean-maize, intercropping winter faba bean/triticale-maize, and triticale-maize. The total TE delivery/ extraction $\left(\mathrm{TE}_{\mathrm{extr}}\right)$ is calculated via

$$
\mathrm{TE}_{\text {extr }}\left[\mathrm{g} \mathrm{ha}^{-1}\right]=y\left[\text { tha }^{-1}\right] * \operatorname{conc}\left[\mathrm{g} \mathrm{t}^{-1}\right]
$$

with yield $(y)$ and element concentration (conc) in the crop.

In Fig. 2 TE delivery is shown as bar charts. There are large variations in total amount of TE delivery, corresponding to the concentration of the elements in the plants and their DM yields. The total amount increases in the sequence $\mathrm{Co}<\mathrm{Ni}<\mathrm{Mo}<\mathrm{Mn}$. For $\mathrm{Co}$ and $\mathrm{Ni}$, only small total amounts were harvested in the range of 0.5 and $3 \mathrm{~g} \mathrm{ha}^{-1} \mathrm{a}^{-1}$. The largest amount of Co could be realized by sole cropping of summer faba beans (about $2 \mathrm{~g} \mathrm{ha}^{-1} \mathrm{a}^{-1}$ ) or double cropping of winter faba bean-maize $\left(1.5 \mathrm{~g} \mathrm{ha}^{-1} \mathrm{a}^{-1}\right)$ and the intercropping of winter faba bean/triticale-maize $\left(1.25 \mathrm{~g} \mathrm{ha}^{-1} \mathrm{a}^{-1}\right)$. The first crops contribute about $90-95 \%$ of total Co delivery and maize as second crop only about $5-10 \%$.

Amaranth results vary between the sites: 1.1 (2015) and $1.35 \mathrm{~g} \mathrm{Co} \mathrm{ha}^{-1}$ (2016) at Sömmerling, compared to $0.6 \mathrm{~g} \mathrm{Co} \mathrm{ha}^{-1}$ at site Reinshof in both years of cultivation. Absolute Mn delivery rates are by far the greatest for all four elements. The pattern resembles that of Mo with highest rates for ryegrass $\left(1.5 \mathrm{~kg} \mathrm{Mn} \mathrm{ha}^{-1} \mathrm{a}^{-1}\right)$ at Sömmerling. The other variants show similar trends for the years according to the results of Tukey's test.
Ryegrass had the greatest delivery rate of Mo (40 to $60 \mathrm{~g} \mathrm{Mo} \mathrm{ha}^{-1} \mathrm{a}^{-1}$, Reinshof). The greatest delivery rates of $\mathrm{Ni}$ were by ryegrass and winter faba bean-maize and summer faba bean (11-14 g Ni ha ${ }^{-1} \mathrm{a}^{-1}$ ) at site Reinshof; at site Sömmerling, only rates smaller than $7.5 \mathrm{~g} \mathrm{Ni} \mathrm{ha}^{-1} \mathrm{a}^{-1}$ could be achieved.

\section{Calculated TE concentrations by applying substrate mixtures in biogas fermenters}

Based on element concentrations of energy crops evaluated in the field trials, hypothetical trace element concentrations in biogas fermenters can be calculated for substrate mixtures. For the calculations, we assume an average-sized stirred mesophilic biogas plant (CSTR) of $500 \mathrm{~kW}$ (electric) and a daily fresh weight input of $20 \mathrm{t}$ of silage. The hydraulic retention time (HRT) is assumed to be 60 days. Each plant substrate faces volume loss according to the conversion of carbon to biogas. An input of $1 \mathrm{t}$ maize (FM) substrate results in only $0.76 \mathrm{t}$ of biogas residue after biogas production. This can be expressed in a mass reduction or degradation factor (F) of 0.76 . Liquid manure only has a $2 \%$ mass reduction, giving a mass reduction factor of 0.98 [44]. For the calculations, the following reduction factors $(\mathrm{F})$ for the substrates were used: maize 0.76 ; faba bean and amaranth 0.8 ; ryegrass 0.75 ; and manure 0.98 (compiled from [44-46]).

Each input substrate is combined with the corresponding mass reduction factor to calculate the mass resulting in the biogas residue. A mixture of $40 \%$ maize $(8 t)$ and $60 \%$ faba bean $(12 \mathrm{t})$ results in $15.68 \mathrm{t}$ after conversion in the biogas residue. To be able to calculate concentrations in biogas fermenters, the concentrations need to be converted to absolute input masses (gram per day) and then divided by the reduced input mass to calculate the concentrations in gram per ton based on fresh matter. For a $40 \%$ maize $(\mathrm{M})$ and $60 \%$ faba bean $(\mathrm{FB})$ input mixture the equation for Co concentration in the fermenter $\left(\mathrm{Co}_{\text {ferm }}\right)$ is

$$
\begin{aligned}
\mathrm{Co}_{\text {ferm }} & =\frac{\operatorname{conc}(M) * \operatorname{input}[t] * F 1+\operatorname{conc}(\mathrm{FB}) * \text { input }[t] * F 2}{15.68 t} \\
& =\frac{0.00266 \mathrm{~g} \mathrm{t}^{-1} \mathrm{FM} * 8 \mathrm{t} * 0.76+0.05 \mathrm{~g} \mathrm{t}^{-1} \mathrm{FM} * 12 \mathrm{t} * 0.80}{15.68 \mathrm{t}} \\
& =\frac{0.498 \mathrm{~g}}{15.68 \mathrm{t}}=0.032 \mathrm{~g} \mathrm{t}^{-1}
\end{aligned}
$$

The other mixtures and TE were calculated in the same way. Note that the plant substrate concentrations were converted to $\mathrm{g} \mathrm{t}^{-1}$ based on fresh weight (FM). The calculation of trace element concentration in biogas plants follows the principles in Reinhold et al. [44] in which a calculation of main nutrient element concentration in fermentation residues is described. This principle also holds for trace elements as all concentrations of the 


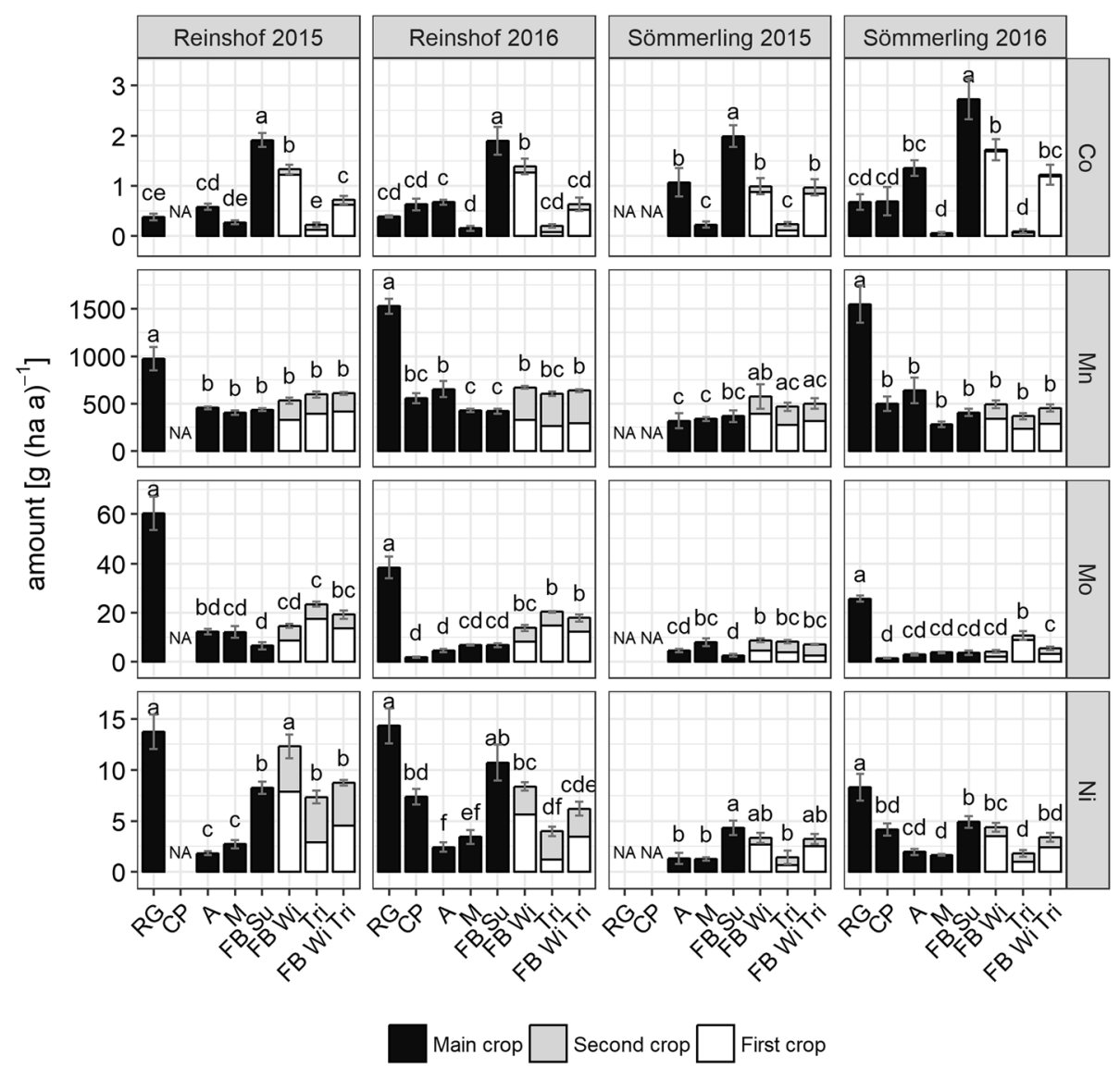

Fig. 2 Element deliveries from field. Mean element deliveries in $\mathrm{g} \mathrm{ha} \mathrm{a}^{-1} \mathrm{a}^{-1}$ for selected variants of all four repetitions on Reinshof and Sömmerling for both years, Second crop = maize as succeeding crop, errorbars = standard errors (SE), different letters indicate significant differences between the variants from Tukey's HSD Test, NA = not available, $\mathrm{RG}=$ ryegrass, $\mathrm{CP}=$ cup plant, $\mathrm{A}=$ amaranth, $\mathrm{M}=$ maize, $\mathrm{FB} \mathrm{Wi}=$ wi faba bean, Tri $=$ triticale, $\mathrm{FB}$ Wi Tri = wi faba bean/triticale

remaining elements are being enriched in the biogas residue.

The mixtures were calculated using the mean concentrations of summer faba bean, ryegrass, and amaranth of both locations. Liquid manure is assumed to contain $8 \%$ $\mathrm{DM}$ and the following element concentrations: Co: 2.25, Ni: 9.1, Mn: 434, Mo: $4.3 \mathrm{mg} \mathrm{kg}^{-1} \mathrm{DM}$ (from own data). Because Co is often the most limiting (from total element concentrations in the plants), the arguments are given in respect to Co threshold values only.

The first mixture shows the resulting concentrations in a biogas plant for a pure maize input (Table 5). Mixtures 1-3 consist only of plants and mixture 4 contains $25 \%$ of liquid manure. The input proportions were calculated based on a daily total fresh matter input of $20 \mathrm{t}$. The pure maize input results in poor Co concentrations of only $0.003 \mathrm{mg} \mathrm{kg}^{-1} \mathrm{FM}$. This is less than $5 \%$ of the Co threshold of $0.07 \mathrm{mg} \mathrm{kg}^{-1}$ FM. Other authors also report critical shortage of elements (especially Co) in pure maize-fed biogas fermenters [7-9] which are usually stabilized by trace element additives. An input mixture of
$40 \%$ maize and $60 \%$ faba bean (mix 3) resulted in $0.032 \mathrm{mg} \mathrm{kg}^{-1} \mathrm{FM}$ giving the greatest Co content in plant based mixtures. This was almost half the threshold of $0.07 \mathrm{mg} \mathrm{kg}^{-1} \mathrm{FM}$ (Table 5, mix 1-3). With a small input of liquid manure (25\% based on FM) plus maize and faba bean, the Co threshold can be surpassed with $0.073 \mathrm{mg} \mathrm{kg}^{-1}$ FM (Table 5, mix 4). The calculated concentrations in a biogas fermenter show that with the addition of alternative energy crops (faba bean, amaranth, ryegrass), a significant portion of Co and other trace elements can be provided. These conclusions are based on the premise that trace elements in the plants are at least as available as trace elements from element additives. However, this aspect is difficult to analyze, as the fermenter contains an anaerobic, reducing environment with numerous possible ligands and binding partners for the elements. All of the regarded trace elements (except $\mathrm{Mn}$ ) do have a high affinity for sulfur and may form sulfides, but this also applies for elements in trace element additives. Some aspects had to be left aside for this simplified calculation. For example, the pure plant 
Table 5 Calculated concentrations in biogas plants/fermenters in $\mathrm{g} \mathrm{t}^{-1}=\mathrm{mg} \mathrm{kg}^{-1} \mathrm{FM}$, of four different substrate input mixtures given in percent and a $100 \%$ maize input (Ref.), based on fresh weight input. Calculated with a total fresh weight input of $20 \mathrm{t}$ per day

\begin{tabular}{llllll}
\hline Mix & Substrates & Co & Mn & Mo & $\mathrm{Ni}$ \\
& & $\mathrm{g} \mathrm{t}^{-1} \mathrm{FM}$ & & & \\
\hline Ref. & M 100\% & 0.003 & 6.2 & 0.13 & 0.06 \\
1 & M 35\%, FB 35\%, A 30\% & 0.025 & 8.8 & 0.12 & 0.09 \\
2 & M 37.5\%, FB 37.5\%, RG 25\% & 0.024 & 11.2 & 0.24 & 0.14 \\
3 & M 40\%, FB 60\% & 0.032 & 8.2 & 0.12 & 0.12 \\
4 & M 35\%, FB 40\%, man. 25\% & 0.073 & 15.9 & 0.18 & 0.30 \\
\hline man. = manure, FM = fresh matter & & & &
\end{tabular}

mixtures calculated in this study would mean a high DM content in the fermenter. Maybe water needed to be added or part of the liquid fraction of the digestate to be recirculated that the stirring units can operate. This handling would also affect the TE content in the fermenter but cannot be included in the calculations. On the other hand, there can be additional positive factors by the input of alternative energy plants to the biocenosis, the microbial growth, and productivity. A microbial community fed by diverse input mixtures is generally less affected by trace element deficiency [9, 47]. Additional research including lab-scale and full-scale biogas plants is required, favorable with assessment of the changes in the microbial community and their activity.

\section{Conclusions}

A promising outcome of this study was that faba bean, amaranth, and ryegrass have a much greater concentration of essential trace elements for biogas production than maize, triticale, or winter rye intercropped with vetch. Especially Co deficiency in biogas plants is likely caused by the low input of Co by the plant substrates. Our field studies showed that faba bean (sole and intercropped with triticale) in a double cropping system with maize can deliver a high DM yield per year and can provide a significant input of $\mathrm{Co}, \mathrm{Ni}$, and $\mathrm{Mn}$ to biogas plants. Furthermore, ryegrass is also a good supplier of $\mathrm{Ni}, \mathrm{Mo}$, and $\mathrm{Mn}$. An input substrate mixture of faba bean, ryegrass, and maize together with a small addition of liquid manure may provide sufficient Co for biogas plants. Flowering mixtures contain elevated trace element concentrations but their DM-yields are too small.

The results of this study reveal the potential of providing trace elements to biogas production in a natural way, without trace element additives. Promoting alternative energy crops will enrich the biodiversity on the field and improve soil quality. This is a very good chance to minimize the use of artificial element additives as they disturb the natural element cycle by remaining in the biogas residue which is reapplied to the fields as fertilizer. In this way, this study is unique in the field of trace element research in biogas production. The majority of studies aim on improving trace element additives and do not focus on natural inputs by plants and small additions of animal manure.

\section{Abbreviations \\ A: Amaranth; AF Mix: Annual flower mixture; AM: Intercropping amaranth/maize; CP: Cup plant; DM: Dry matter; FB Su: Summer faba bean; FB Wi Tri: Intercropping faba bean/triticale; FB Wi: Winter faba bean; FM: Fresh matter; M: Maize; PF Mix: Perennial flower mixture; RG: Ryegrass; RV: Intercropping rye/vetch; TE: Trace elements; TF: Transfer factor; Tri: Winter triticale}

\section{Acknowledgements}

The authors thank T. Seibold for management of the field work. We thank Prof. R. Rauber and Dr. C. Meinen for helpful comments on the manuscript.

\section{Funding}

The investigations were carried out within the joint research project: trace elements by energy crops - mass fluxes and recommendations for an optimized process biology in biogas plants. Project partners are the German Biomass Research Centre-DBFZ and the Helmholtz Centre for Environmental Research-UFZ. The research was funded by the BMEL (German Federal Ministry of Food and Agriculture, Berlin) via the FNR (Agency for Renewable Resources, Gülzow, Germany (FKZ: 22019014, 22014813).

\section{Availability of data and materials}

All data needed for the results and final conclusions is included.

\section{Authors' contributions}

WF wrote the manuscript (65\%), took soil and plant samples, did the element analysis, and performed the statistics. KH supervised the field experiment (crop management, soil sampling, plant sampling) and did yield and data analysis, performed the statistics, and wrote the manuscript (35\%). BS is the project manager, did the acquisition of funding, and improved the manuscript. HR contributed in the acquisition of funding and improved the manuscript. All authors read and approved the final manuscript.

Ethics approval and consent to participate

Not applicable.

\section{Consent for publication}

Not applicable.

\section{Competing interests}

The authors declare that they have no competing interests.

\section{Publisher's Note}

Springer Nature remains neutral with regard to jurisdictional claims in published maps and institutional affiliations.

\section{Author details}

${ }^{1}$ Department of Sedimentology and Environmental Geology, Georg-August University, Goldschmidtstraße 3, 37075 Göttingen, Germany. ${ }^{2}$ Department of Crop Sciences, Division of Agronomy, Georg-August University,

Von-Siebold-Str.8, 37075 Göttingen, Germany.

Received: 14 March 2018 Accepted: 6 November 2018

Published online: 01 December 2018

\section{References}

1. Biogas Fachverband. Biogas market data in Germany 2016/2017 (pdf); 2017. Available from: https://www.biogas.org/edcom/webfvb.nsf/id/EN-Germanbiogas-market-data. Acccessed Oct 2016

2. Bauernverband D. Biogas stabilisiert Einkünfte in der Landwirtschaft; 2018. Available from: http://www.bauernverband.de/biogas-stabilisiert-einkuenftein-der-landwirtschaft. Accessed Feb 2018 
3. Daniel-Gromke J, Rensberg N, Denysenko V, Trommler M, Reinholz T, Völler $\mathrm{K}$, et al. Anlagenbestand Biogas und Biomethan - Biogaserzeugung und -nutzung in Deutschland. DBFZ Report Nr 30, Leipzig. 2017.

4. Vertès RC, Mary B (2007) Modelling the long term SOM dynamics in fodder rotations with a variable part of grassland. In: "Organic Matter Symposium", 17-19 July 2007, Poitiers, France, p 549-550

5. Palmer RC, Smith RP (2013) Soil structural degradation in SW England and its impact on surface-water runoff generation. Soil Use Manage 29(4):567-575

6. Labatte JM, Got B (1991) Modelling damage on maize by the European Corn Borer, Ostrinia nubilalis. Ann Appl Biol 119(3):401-413

7. Lebuhn M, Liu F, Heuwinkel H, Gronauer A (2008) Biogas production from mono-digestion of maize silage-long-term process stability and requirements. Water Sci Technol 58(8):1645-1651

8. Hinken L, Urban I, Haun E, Weichgrebe D, Rosenwinkel KH (2008) The valuation of malnutrition in the mono-digestion of maize silage by anaerobic batch tests. Water Sci Technol 58(7):1453

9. Pobeheim H, Munk B, Lindorfer H, Guebitz GM (2011) Impact of nickel and cobalt on biogas production and process stability during semi-continuous anaerobic fermentation of a model substrate for maize silage. Water Res 45(2):781-787

10. Lindorfer H, Ramhold D, Frauz B (2012) Nutrient and trace element supply in anaerobic digestion plants and effect of trace element application. Water Sci Technol 66(9):1923

11. Choong YY, Norli I, Abdullah AZ, Yhaya MF (2016) Impacts of trace element supplementation on the performance of anaerobic digestion process: A critical review. Bioresour Technol 209:369-379

12. Demirel B, Scherer $P(2011)$ Trace element requirements of agricultural biogas digesters during biological conversion of renewable biomass to methane. Biomass Bioenergy 35(3):992-998

13. Sauer B (2010) Elementgehalte und Stoffströme bei der Strom- und Wärmegewinnung im Bioenergiedorf Jühnde. Schriftenreihe: Fortschritt neu denken 2:1-166

14. Weiland $P(2006)$ Biomass digestion in agriculture: a successful pathway for the energy production and waste treatment in Germany. Eng Life Sci 6(3):302-309

15. Kuttner $P$, Weißböck AD, Leitner $V$, Jäger $A$ (2015) Examination of commercial additives for biogas production. Agron Res 13(2):337-347

16. He ZL, Yang XE, Stoffella PJ (2005) Trace elements in agroecosystems and impacts on the environment. J Trace Elem Med Bio 19(2-3):125-140

17. Amnesty International (2016) This is what we die for: human right abuses in the Democratic Republic of Congo power the global trade in cobalt, London Available from: https:/www.amnesty.org/en/documents/ afr62/3183/2016/en/. Accessed Mar 2018

18. Kabata-Pendias A (2004) Soil-plant transfer of trace elements-an environmental issue. Geoderma 122(2-4):143-149

19. Palit S, Sharma A, Talukder (1994) Effects of cobalt on plants. Bot Rev 60(2): 149-181 Available from: http://www.jstor.org/stable/4354226

20. Marschner H (1995) Mineral nutrition of higher plants, 2nd edn. Academic Press, London and San Diego

21. Hänsch R, Mendel RR (2009) Physiological functions of mineral micronutrients (Cu, Zn, Mn, Fe, Ni, Mo, B, Cl). Curr Opin Plant Biol 12(3):259-266

22. Reisenauer HM (1960) Cobalt in nitrogen fixation by a legume. Nature 186(4722):375-376

23. Kessler E, Arthur W, Brugger JE (1957) The influence of manganese and phosphate on delayed light emission, fluorescence, photoreduction and photosynthesis in algae. Arch Biochem Biophys 71(2):326-335

24. Arnon DI, Stout PR (1939) Molybdenum as an essential element for higher plants. Plant Physiol 14(3):599-602

25. Kaiser BN, Gridley KL, Ngaire Brady J, Phillips T, Tyerman SD (2005) The role of molybdenum in agricultural plant production. Ann Bot 96(5):745-754

26. Shkolnik MY (1984) Trace elements in plants. vol. 6 of Developments in crop science. Elsevier, Amsterdam; Oxford

27. Dixon NE, Gazzola C, Blakeley RL, Zerner B (1975) Jack bean urease (EC 3.5.1.5). A Metalloenzyme. A Simple biological role for nickel. J Am Chem Soc 97(14):4131-4133. https://doi.org/10.1021/ja00847a045

28. Eskew DL, Welch RM, Norvell WA (1984) Nickel in higher plants: further evidence for an essential role. Plant Physiol 76(3):691-693

29. Reimann C, Fabian K, Birke M, Filzmoser P, Demetriades A, Négrel P et al (2018) GEMAS: Establishing geochemical background and threshold for 53 chemical elements in European agricultural soil. Appl Geochem 88:302-318
30. Deutscher Wetterdienst (German Metereological Service), DWD; 2017

31. DIN ISO 10390:2005. Soil quality-determination of pH; 2005

32. Thun R, Hoffmann G (2012) In: Bassler R (ed) Die Untersuchung von Böden. vol. 1 Handbuch der landwirtschaftlichen Versuchs- und Untersuchungsmethodik: (Methodenbuch), 4th edn. VDLUFA-Verl, Darmstadt

33. DIN ISO 11277:2002-08. Soil quality-determination of particle size distribution in mineral soil material method by sieving and sedimentation; 2002

34. Zorn W, Heß H, Albert E, Hartmut Kolbe K, Franke G. Düngung in Thüringen nach "guter fachlicher Praxis". Landwirtschaft und Landschaftspflege in Thüringen. 2007;7:1-186. http://www.tll.de/www/daten/publikationen/ schriftenreihe/dung0108.pdf

35. Pospiech S, Fahlbusch W, Sauer B, Pasold T, Ruppert H (2017) Alteration of trace element concentrations in plants by adhering particles - Methods of correction. Chemosphere 182:501-508

36. R Core Team. R: A language and environment for statistical computing. Vienna, Austria; 2017. Available from: https://www.R-project.org/.

37. Bates D, Mächler M, Bolker B, Walker S (2015) Fitting linear mixed-effects models using Ime4. J Stat Softw 67(1):1-48

38. Hothorn T, Bretz F, Westfall P (2008) Simultaneous inference in general parametric models. Biom J 50(3):346-363

39. Wickham H (2016) ggplot2: Elegant Graphics for Data Analysis. SpringerVerlag, New York Available from: http://ggplot2.org

40. Graß R, Heuser F, Stülpnagel R, Piepho HP, Wachendorf M (2013) Energy crop production in double-cropping systems: Results from an experiment at seven sites. Eur J Agron 51:120-129

41. von Cossel M, Lewandowski I (2016) Perennial wild plant mixtures for biomass production: impact of species composition dynamics on yield performance over a five-year cultivation period in southwest Germany. Eur J Agron 79:74-89

42. Schoo B, Wittich KP, Böttcher U, Kage H, Schittenhelm S (2017) Drought tolerance and water-use efficiency of biogas crops: a comparison of cup plant, maize and lucerne-grass. J Agron Crop Sci 203(2):117-130

43. Hartmann A, Lunenberg T (2016) Yield potential of cup plant under Bavarian conditions. J Cultiv. Plants 68:385-388

44. Reinhold G, Breitschuh G, Herold L, Zorn W (2006) Ermittlung der Nährstoffgehalte und zur Nährstoffbilanzierung bei Einsatz von Biogasgülle. Thüringer Landesanstalt für Landwirtschaft, Jena

45. Möller K, Schulz R, Müller T (2010) Substrate inputs, nutrient flows and nitrogen loss of two centralized biogas plants in southern Germany. Nutr Cycl Agroecosys 87(2):307-325

46. Reinhold G (2005) Masse- und Trockensubstanzbilanz in landwirtschaftlichen Biogasanlagen. Neue Landwirtschaft 12:68-72 Available from: https://www. researchgate.net/publication/265236203_Masse-und_Trockensubstanzbilanz in landwirtschaftlichen_Biogasanlagen

47. Wall DM, Allen E, Straccialini B, O'Kiely P, Murphy JD (2014) The effect of trace element addition to mono-digestion of grass silage at high organic loading rates. Bioresour Technol 172:349-355

Ready to submit your research? Choose BMC and benefit from:

- fast, convenient online submission

- thorough peer review by experienced researchers in your field

- rapid publication on acceptance

- support for research data, including large and complex data types

- gold Open Access which fosters wider collaboration and increased citations

- maximum visibility for your research: over $100 \mathrm{M}$ website views per year

At BMC, research is always in progress.

Learn more biomedcentral.com/submissions 